\title{
Mechanism of Hydrogen Formation in Trichomonas foetus
}

\author{
By T. BAUCHOP* \\ Wellcome Laboratories of Tropical Medicine, \\ Euston Road, London, N.W. I \\ (Accepted for publication 21 June 197I)
}

\begin{abstract}
SUMMARY
Carbohydrate fermentation by the flagellate protozoan Trichomonas foetus results in the production of large amounts of hydrogen by an unknown mechanism. Impermeability of $T$. foetus to pyruvate at neutral $\mathrm{pH}$ may explain earlier failures of other workers to demonstrate unequivocally the intermediate participation of pyruvate in this fermentation. Intact cells of $T$. foetus have now been shown to ferment pyruvate at $\mathrm{pH} 44^{\circ}$. In addition pyruvate is metabolized rapidly at $\mathrm{pH} 6{ }^{\circ} \mathrm{O}$ by cell-free extracts although not by intact cells. Extracts of $T$. foetus have been found to convert pyruvate to equimolar amounts of acetate, $\mathrm{H}_{2}$ and $\mathrm{CO}_{2}$. Formate was not metabolized by either intact cells or extracts, although an active hydrogenase was present. It is concluded that this protozoan possesses a mechanism of hydrogen formation similar to that found in the saccharolytic clostridial bacteria.
\end{abstract}

\section{INTRODUCTION}

In protozoa, hydrogen is a common end-product of carbohydrate fermentation (Bragg \& Reeves, I962; von Brand, I966), but a mechanism for hydrogen formation has not been described. In bacteria, where hydrogen is also a common fermentation product, two distinct mechanisms of formation have been identified, both involving intermediate formation of pyruvate. In the Enterobacteriaceae pyruvate is converted to acetyl coenzyme $A$ and formate in a thioclastic reaction. Formate is normally further metabolized to $\mathrm{H}_{2}$ and $\mathrm{CO}_{2}$ by formic hydrogenylase. Saccharolytic clostridia also cleave pyruvate to acetyl coenzyme $\mathrm{A}, \mathrm{H}_{2}$ and $\mathrm{CO}_{2}$ but formate is not an intermediate in this reaction.

In the flagellated protozoan Trichomonas foetus hydrogen is a major product of carbohydrate fermentation (Suzuoki \& Suzuoki, I95I; Ryley, 1955). Evidence is presented that hydrogen is formed by a reaction similar to that found in saccharolytic clostridial bacteria.

\section{METHODS}

Organism. Trichomonas foetus was obtained from M. D. Pittam, Lister Institute of Preventive Medicine, London.

Medium. Difco Bacto N.I.H. thioglycollate broth with the addition of $7 \%(\mathrm{v} / \mathrm{v})$ horse serum was used for culture maintenance and cell production.

Conditions of growth. Anaerobic conditions were employed when Trichomonas foetus was grown for biochemical studies. A $500 \mathrm{ml}$. Erlenmeyer flask containing $400 \mathrm{ml}$. medium was autoclaved at $12 \mathrm{I}^{\circ}$. for $\mathrm{I} 5 \mathrm{~min}$. The flask was removed from the autoclave and

* Present address: Department of Experimental Pathology, Rowett Research Institute, Bucksburn, Aberdeen. 
cooled rapidly to prevent excessive oxidation of the medium. Horse serum (40 ml.) was added aseptically together with a $50 \mathrm{ml}$. inoculum of an actively fermenting culture of $T$. foetus. These additions filled the flask close to the neck. The culture was incubated for I 8 to $20 \mathrm{~h}$. at $37^{\circ}$. Gases evolved during the resultant fermentation maintained the culture under anaerobic conditions.

Harvesting of the organisms was accomplished by centrifuging at $\mathrm{I} 200 \mathrm{~g}$ for $5 \mathrm{~min}$. The organisms were washed once in $0.9 \%(\mathrm{w} / \mathrm{v}) \mathrm{NaCl}$ and resuspended in a small volume of saline.

Cell-free extracts were prepared by treating suspensions (10 ml.) of protozoa in a M.S.E. ultrasonic disintegrator $\left(3 / 4 \mathrm{in}\right.$. probe) for $\mathrm{I}$ min. at $0^{\circ}$. Routine microscopic examination of these preparations demonstrated the efficacy of this method. Cellular debris was generally removed by centrifugation at $\mathrm{I} 600 \mathrm{~g}$.

Pyruvic acid was estimated by the method of Friedemann \& Haugen (I943).

Steam-volatile acids were distilled by the method of Markham (1942) and estimated by titration with a Conway microburette. When pyruvic acid was present in the reaction mixtures the $\mathrm{pH}$ was adjusted to 3.5 to prevent pyruvic acid being distilled (Lewis \& Elsden, 1955).

Protein nitrogen was estimated by the method of Lowry, Rosebrough, Farr \& Randall (I95I).

Manometric methods. Standard manometric techniques were followed. All experiments were performed at $37^{\circ}$ under an atmosphere of $\mathrm{N}_{2}$ or $\mathrm{H}_{2}$ as indicated. In gas-evolution experiments hydrogen was measured with $20 \%(\mathrm{w} / \mathrm{v}) \mathrm{KOH}$ in the centre-well of the flasks. By use of paired flasks carbon dioxide was determined from total gas evolved minus hydrogen gas evolved.

\section{Permeability to pyruvate}

RESULTS

Intact cells of Trichomonas foetus normally possess a high endogenous metabolism due to utilization of glycogen reserves (Ryley, I955; Manners \& Ryley, I955). At pH 6.0 addition of glucose to intact organisms produced variable stimulation of gas production and was frequently without appreciable effect (Table I, Expt. I). The variable stimulation

\section{Table I. Effect of $\mathrm{pH}$ on gas production from different substrates}

\section{by Trichomonas foetus}

The system contained $50 \mu$ mole substrate (side arm); $1.0 \mathrm{ml}$. cell suspension ( $\mathrm{I}^{8}$ organisms in $0.9 \%(\mathrm{w} / \mathrm{v}) \mathrm{NaCl})$; total volume $2.8 \mathrm{ml}$.; atmosphere $\mathrm{N}_{2}$. The buffers used were: Expt. I, $130 \mu$ mole potassium phosphate, pH 6.0; Expt. 2, potassium phosphate-citric acid, pH 5.0 (Gomori, 1955); Expt. 3, as for Expt. 2 except that pH was 4.0 ; Expt. 4, as for Ex)ts I, 2 and 3. Gas evolution was linear during at least the first $10 \mathrm{~min}$. of the incubation pariod.

\begin{tabular}{|c|c|c|c|c|c|}
\hline \multirow[b]{2}{*}{ Experiment } & \multirow[b]{2}{*}{$\mathrm{pH}$} & \multicolumn{4}{|c|}{ Gas produced $(\mu 1 . / \mathrm{h})}$. \\
\hline & & Endogenous & $\begin{array}{c}\text { Endogenous } \\
+ \\
\text { glucose }\end{array}$ & $\begin{array}{c}\text { Endogenous } \\
+ \\
\text { pyruvate }\end{array}$ & $\begin{array}{c}\text { Endogenous } \\
+ \\
\text { formate }\end{array}$ \\
\hline I & $6 \cdot 0$ & 444 & 462 & 408 & 462 \\
\hline 2 & $5 \cdot 0$ & 207 & 798 & 546 & 219 \\
\hline 3 & 4.0 & 0 & 0 & 648 & 0 \\
\hline \multirow[t]{3}{*}{4} & $6 \cdot 0$ & 330 & - & 390 & -- \\
\hline & $5 \cdot 0$ & 370 & - & 460 & - \\
\hline & $4 \cdot 0$ & 20 & $\ldots$ & 650 & - \\
\hline
\end{tabular}


of gas production by exogenous glucose is presumably a function of the status of cellular glycogen reserves. However, regardless of the efficacy of exogenous glucose in stimulating gas production, stimulation by pyruvate or formate could not be unequivocally demonstrated at $\mathrm{pH} 6 \cdot 0$ or $7^{\circ} \mathrm{O}$. The failure of pyruvate to stimulate gas production could be explained by cellular impermeability to pyruvate.

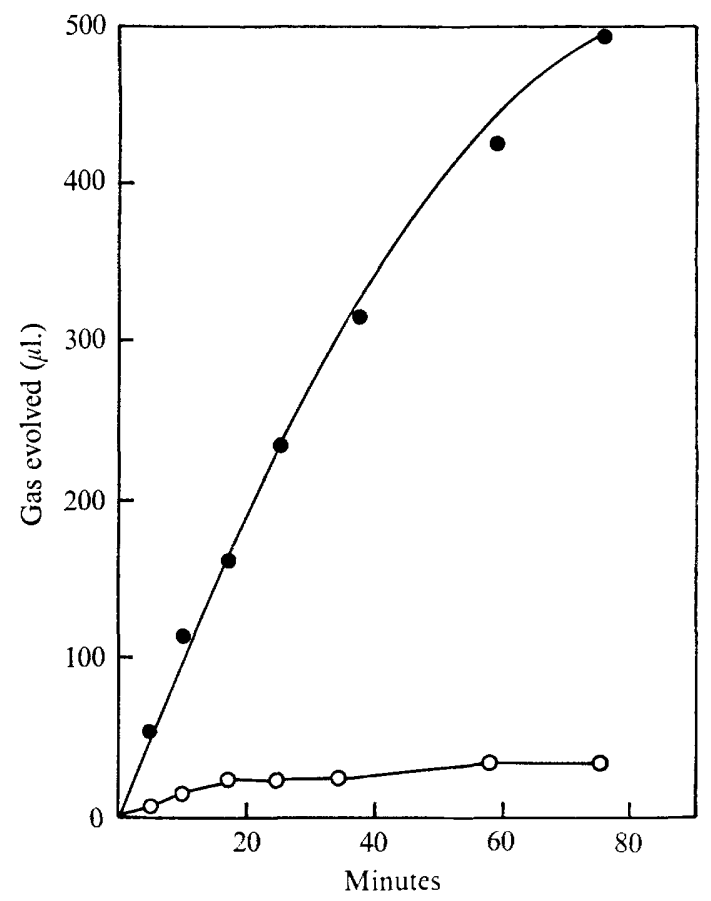

Fig. I. Pyruvate fermentation at pH 6.0 by cell-free extracts of Trichomonas foetus. Details as for Expt. I (Table I) except that the suspension of organisms was treated in the ultrasonic disintegrator as described. The resultant cell-free preparations were immediately pipetted into previously prepared Warburg flasks. Endogenous, $O$; pyruvate,

Absorption of organic acids by micro-organisms is frequently facilitated at acid $\mathrm{pH}$. At $\mathrm{pH} 5^{\circ}$, endogenous metabolism of Trichomonas foetus was partially suppressed; both glucose and pyruvate stimulated gas production but again formate was not metabolized (Table I, Expt. 2). The lower fermentation rate with pyruvate relative to glucose suggested that cellular permeability might be rate-limiting. This possibility was further examined by measuring fermentation rates with these substrates at $\mathrm{pH} 4 \cdot 0$ (Table I, Expt. 3). Although endogenous activity was absent and neither glucose nor formate was metabolized, pyruvate was fermented rapidly. Microscopic examination of incubation mixtures at termination of this experiment demonstrated that the organisms remained intact. The high rate of pyruvate fermentation under these conditions was additional evidence that activity was a function of $\mathrm{pH}$ and related to cellular permeability. In an experiment with the same cell suspension at different $\mathrm{pH}$ values, pyruvate fermentation was confirmed to be $\mathrm{pH}$ dependent (Table I, Expt. 4).

A rapid fermentation of pyruvate by cell-free extracts at $\mathrm{pH} 6.0$ demonstrated that high activity could be obtained after rupture of cellular membranes (Fig. I). In Trichomonas foetus, permeability to pyruvate is a factor limiting the rate of pyruvate fermentation. This 
phenomenon may explain the failure of earlier workers to demonstrate pyruvate fermentation at neutral $\mathrm{pH}$.

\title{
Pyruvate metabolism
}

Cell-free extracts of Trichomonas foetus produced equimolar proportions of $\mathrm{H}_{2}$ and $\mathrm{CO}_{2}$ from pyruvate (Table 2). As these preparations were readily inhibited by oxygen, high activity could be obtained only with strict anaerobic techniques. In one experiment, storage of extract in the refrigerator for $20 \mathrm{~min}$. without anaerobic precautions, resulted in $75 \%$ loss of activity. This may explain the earlier failure of Lindblom (I96I) to demonstrate pyruvate metabolism with extracts of $T$. foetus.

\section{Table 2. Products of pyruvate metabolism by cell-free extracts of Trichomonas foetus}

\begin{abstract}
The system contained $14 \mu$ mole sodium pyruvate (side arm); $130 \mu$ mole potassium phosphate; $1.0 \mathrm{ml}$. extract $(2.7 \mathrm{mg}$. N/ml.); pH 6.2; total volume $3.0 \mathrm{ml} . ; 0.2 \mathrm{ml} .20 \%(\mathrm{w} / \mathrm{v}) \mathrm{KOH}$ in the centre-well for measurement of hydrogen; atmosphere $\mathrm{N}_{2}$. Incubation time was $50 \mathrm{~min}$. No endogenous activity was detected.
\end{abstract}

$\begin{array}{lcc} & \mu \text { mole } & \text { mole/mole pyruvate } \\ \text { Pyruvate utilized } & \mathrm{I} 4 \cdot 0 & - \\ \text { Acetate } & \mathrm{I} 4.4 & \mathbf{I} \cdot 03 \\ \mathrm{H}_{2} & \mathrm{I} 3.8 & 0.99 \\ \mathrm{H}_{2}+\mathrm{CO}_{2} & 26 \cdot \mathrm{I} & \mathbf{I} \cdot 87\end{array}$

Chemical analysis of the fermentation products demonstrated that pyruvate was metabolized according to the following equation (Table 2).

$$
\mathrm{CH}_{3} \mathrm{COCOOH}+\mathrm{H}_{2} \mathrm{O} \rightarrow \mathrm{CH}_{3} \mathrm{COOH}+\mathrm{H}_{2}+\mathrm{CO}_{2} \text {. }
$$

The stoichiometry of this equation is satisfied by either of the pathways of hydrogen formation found in bacteria. Determination of the operative pathway depends upon the demonstration of formate participation. Intact bacteria are normally permeable to formate, and formic hydrogenylase has been demonstrated in cell suspensions of different bacteria grown anaerobically (Stephenson \& Stickland, I932; Bauchop \& Dawes, 1959). Intact cells of Trichomonas foetus, grown anaerobically, did not metabolize formate at any of the $\mathrm{pH}$ values tested, which ranged from $4 \cdot 0$ to $7 \cdot 2$. Under all of the conditions tested, $\mathrm{H}_{2}$ and $\mathrm{CO}_{2}$ were produced from glucose, pyruvate or endogenous carbohydrate reserves, which demonstrated that the hydrogen-forming mechanism was operative. Formic dehydrogenase is associated with formic hydrogenlyase activity in bacteria and has also been demonstrated in intact organisms (Stephenson \& Stickland, 1932; Bauchop \& Dawes, 1959). Formic dehydrogenase, with methylene blue as acceptor, could not be demonstrated in intact $T$. foetus at $\mathrm{pH} 6 \cdot 0$ or $7 \cdot 0$. These experiments suggested that enzymes for formate catabolism were absent or, alternatively, cells of $T$. foetus were impermeable to formate. In numerous experiments, at different $\mathrm{pH}$ values, cell-free extracts were tested for formic hydrogenlyase and formic dehydrogenase. These activities could not be demonstrated in extracts which exhibited a high rate of production of $\mathrm{H}_{2}$ and $\mathrm{CO}_{2}$ from pyruvate. It was concluded that formate does not participate in the mechanism of hydrogen formation in $T$. foetus. Hydrogen would thus appear to be formed by a reaction resembling that found in clostridial bacteria. 


\section{Hydrogenase}

Hydrogenase is an essential component of the hydrogen-forming enzyme complex in saccharolytic clostridia (Gest, I954). Intact cells of Clostridium acetobutylicum exhibit an active hydrogenase with methylene blue as acceptor (Davies, 1942). Although C. butylicum does not possess hydrogenase activity with methylene blue (Koepsell \& Johnson, 1942)

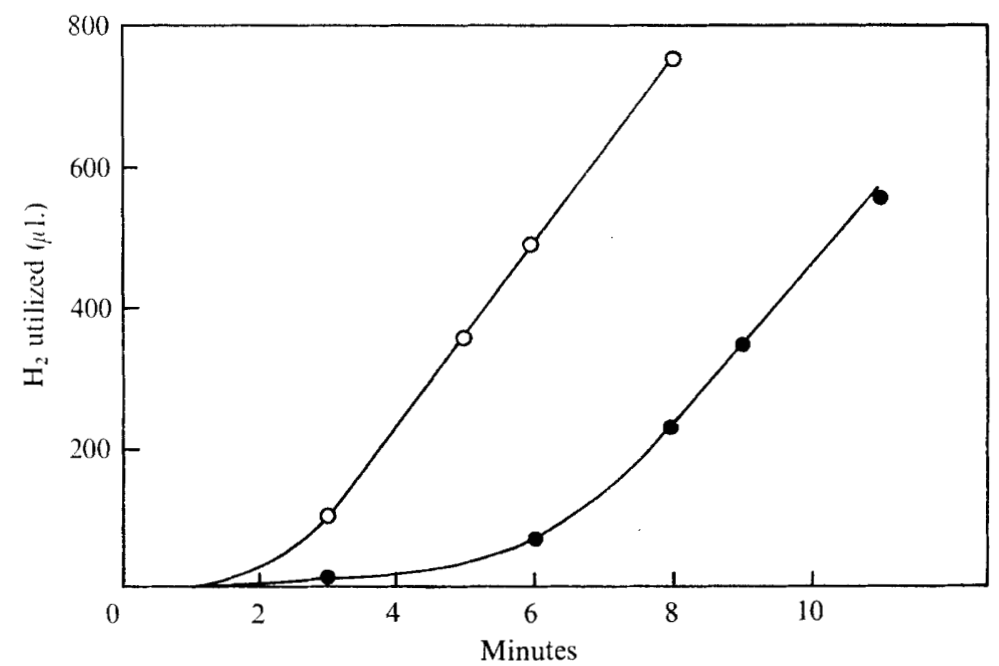

Fig. 2. Hydrogenase in intact Trichomonas foetus. Warburg flasks contained: $50 \mu$ mole methylene blue (side arm); $60 \mu$ mole potassium phosphate; $5 \mu$ mole sodium dithionite where indicated; $\mathrm{r} .0 \mathrm{ml}$. cell suspension ( $10^{8}$ organisms in $\left.0.9 \%(\mathrm{w} / \mathrm{v}) \mathrm{NaCl}\right) ; \mathrm{pH} 7 \cdot 2 ; 0.2 \mathrm{ml} .20 \%(\mathrm{w} / \mathrm{v}) \mathrm{KOH}$ in the centre-well; total volume $3.0 \mathrm{ml}$; atmosphere $\mathrm{H}_{2}$. Endogenous activity was absent. Control flasks with boiled organisms possessed no activity. Dithionite absent, 9 ; dithionite present, $\bigcirc$.

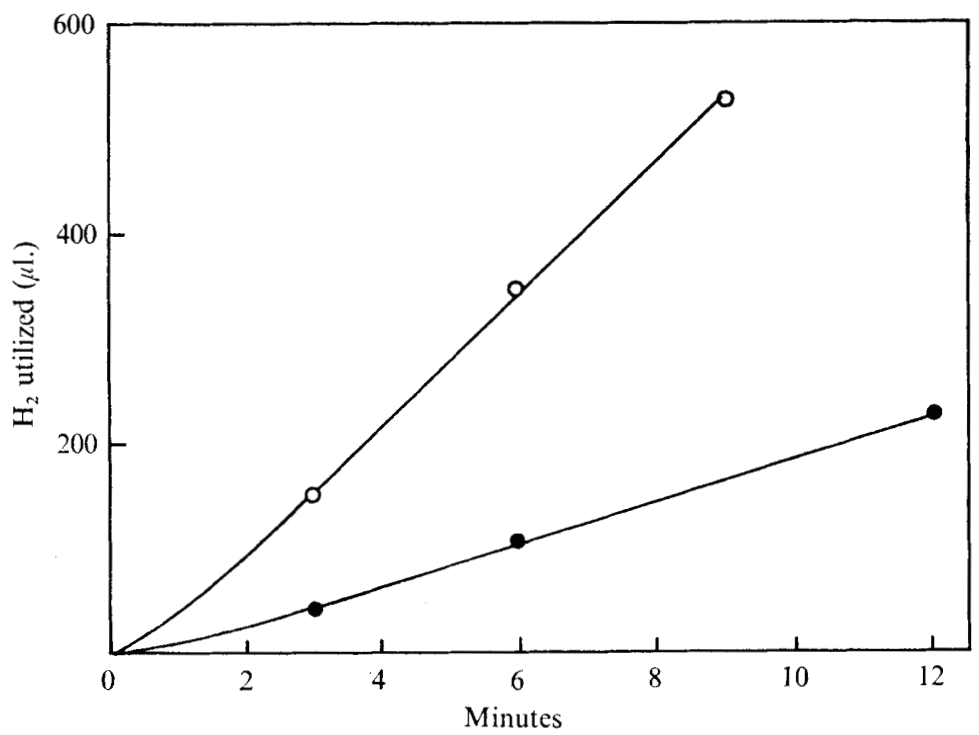

Fig. 3. Hydrogenase in cell-free extracts of Trichomonas foetus. Details as for Fig. 2 except that $\mathrm{I} \cdot 0 \mathrm{ml}$. extract $(2 \cdot 1 \mathrm{mg} . \mathrm{N} / \mathrm{ml}$.) replaced the suspension of organisms. Dithionite absent, dithionite present, $O$. 
hydrogenase has been demonstrated with the violagen dyes (Peck \& Gest, I957). In Trichomonas foetus hydrogenase was demonstrated in intact cells with methylene blue as acceptor (Fig. 2). A frequently observed induction period could be largely eliminated by addition of small quantities of sodium dithionite. Similar results were reported with the hydrogenases of Escherichia coli (Joklik, I950) and Sarcina ventriculi (Bauchop \& Dawes, 1968). Hydrogenase was demonstrated also in extracts of T. foetus (Fig. 3). Sodium dithionite stimulated activity in extracts and could also restore activity to inactive preparations of the enzyme. These results indicated that the hydrogenase of $T$. foetus was inhibited by oxygen. Fisher, Krasna \& Rittenberg (1954) demonstrated that the hydrogenase of Escherichia coli was inhibited by oxidation and reversible oxygenation.

\section{DISCUSSION}

Lindblom (196I) has examined several species of Trichomonas for enzymes concerned with hydrogen formation. His data demonstrated that he was unable to obtain definite evidence for formic hydrogenlyase or hydrogenase (von Brand, I966). However, evidence was presented for an active formic dehydrogenase. This could not be confirmed in the present study. With conventional manometric techniques Lindblom used $5 \times 10^{7}$ cells of Trichomonas foetus/flask, but expressed gas evolution in terms of cellular nitrogen. A factor relating protozoal numbers to cellular nitrogen content was not published. Therefore the gas evolution which was measured could not be determined from this data. With T. foetus, Ryley (1955) found that $5 \times 10^{7}$ cells contained approximately $0.5 \mathrm{mg}$. cellular nitrogen. If we apply this factor to the formic dehydrogenase experiment of Lindblom (I96I) the volume of gas evolved during the experiment is calculated to be $47 \mu \mathrm{l} . \mathrm{CO}_{2}$. This level of activity is not acceptable evidence for the presence of formic dehydrogenase in $T$. foetus. The present results agree with the finding of Ryley (1955) that formate was not metabolized by either intact cells or cell homogenates. With intact cells or extracts the demonstration of hydrogen formation from pyruvate, but not formate, is strong evidence for non-participation of formate in this reaction sequence.

In protozoa, as in bacteria, the various products of carbohydrate fermentation are formed via alternate pathways of pyruvate metabolism. A yeast-like pyruvic decarboxylase has been demonstrated in Strigomonas oncopelti (Bauchop, 1962). The present demonstration of a clostridial-like fission of pyruvate extends the known reactions of pyruvate dissimilation in protozoa.

\section{REFERENCES}

BAUCHOP, T. (1962). Ethanol formation in Strigomonas oncopelti. Biochemica et biophysica acta 59, $742-743$. Bauchop, T. \& Dawes, E. A. (1959). Metabolism of pyruvic and formic acids by Zymosarcina ventriculi. Biochimica et biophysica acta 36, 294-296.

BAuchor, T. \& DAWES, E. A. (1968). The metabolism of formic acid by Sarcina ventriculi. Journal of General Microbiology 52, 195-203.

Bragg, P. D. \& ReEves, R. E. (1962). Pathways of glucose dissimilation in the Laredo strain of Entamoeba histolytica. Experimental Parasitology 12, 393-400.

Brand, T. von (1966). Biochemistry of Parasites. New York: Academic Press.

DAvies, R. (1942). Studies on the acetone-butyl alcohol fermentation. II. Intermediates in the fermentation of glucose by Clostridium acetobutylicum. Biochemical Journal 36, 582-599.

Fisher, H. F., Krasna, A. I. \& Rittenberg, D. (1954). The interaction of hydrogenase with oxygen. Journal of Biological Chemistry 209, 569-578.

Friedemann, T. E. \& Haugen, G. E. (I943). Pyruvic acid. II. The determination of keto acids in blood and urine. Journal of Biological Chemistry 147, 415-442. 
GEST, H. (1954). Oxidation and evolution of molecular hydrogen by micro-organisms. Bacteriological Reviews $18,43-73$.

Gomori, G. (I955). Preparation of buffers for use in enzyme studies. Methods in Enzymology I, I38-I46.

JoKLIK, W. K. (1950). The hydrogenase of Escherichia coli in the cell-free state. I. Concentration, properties and activation. Australian Journal of Experimental Biology and Medical Science 28, 32 I-329.

Koepsell, H. J. \& Johnson, M. J. (I942). Dissimilation of pyruvic acid by cell-free preparations of Clostridium butylicum. Journal of Biological Chemistry $\mathbf{1 4 5}, 379-386$.

LewIS, D. \& ElSDEN, S. R. (1955). The fermentation of L-threonine, L-serine, L-cysteine and acrylic acid by a Gram-negative coccus. Biochemical Journal 6o, 683-692.

LindBLOM, G. P. (1961). Carbohydrate metabolism of trichomonads: growth, respiration, and enzyme activity in four species. Journal of Protozoology 8, 139-150.

Lowry, O. H., Rosebrough, N. J., Farr, A. L. \& Randall, R. J. (I95I). Protein measurement with the Folin phenol reagent. Journal of Biological Chemistry 193, 265-275.

MARKhAM, R. (1942). A steam distillation apparatus suitable for micro-Kjeldahl analysis. Bio chemica Journal 36, 790-79I.

ManNeRs, D. J. \& RYLeY, J. F. (I955). Studies on the metabolism of protozoa. VI. The glycogens of the parasitic flagellates Trichomonas foetus and Trichomonas gallinae. Biochemical Journal 59, 369-372.

PECK, H. D., JUn. \& GeST, H. (1957). Hydrogenase of Clostridium butylicum. Journal of Bacteriology 73, 569-580.

RYLEY, J.F. (1955). Studies on the metabolism of protozoa. V. Metabolism of the parasitic flagellate Trichomonas foetus. Biochemical Journal 59, 36I-369.

Stephenson, M. \& Stickland, L. H. (1932). Hydrogenlyases. Bacterial enzymes liberating molecular hydrogen. Biochemical Journal 26, 712-724.

SUZUOKI, J. \& SUZUOKI, T. (195I). Carbohydrate metabolism of Trichomonas foetus. Journal of Biochemistry, Tokyo 38, 237-254. 